Original article

\title{
Metropolitan aspirations of cities in East Poland during the process of their
}

\author{
development
}

\author{
Jolanta Rodzoś, Monika Wesołowska
}

Department of Social and Economic Geography, Faculty of Earth Sciences and Spatial Management Maria Curie-Skłodowska University in Lublin, Kraśnicka Str. 2 c,d, 24-220 Lublin, Poland

E-mail address (corresponding author): jolanta.rodzos@poczta.umcs.lublin.pl

\begin{abstract}
Białystok, Lublin, and Rzeszów are the three largest cities in eastern Poland, and the capitals of their provinces. They each have metropolitan ambitions, and based on partner agreements with the authorities of their neighbouring districts they initiated the establishment of metropolitan areas where they became the main centres. This article undertakes an analysis of a number of elements of each of these metropolitan areas in order to compare their position, and to give an assessment of the development of their metropolitan functions. The analysis concerned their demographic, social, economic and cultural parameters. Results of this research show that none of these analysed cities has yet developed sufficient functions coherent with the European metropolitan network. Each of them is a strong regional centre of national importance. Statistical analysis of the data shows no strong leader among these three metropolitan areas. The weak position of the Białystok Metropolitan Area is evident due to its particularly disturbing demographic processes which offer no chance for population development in the area or growth of its social potential. The Rzeszów Metropolitan Area maintains the best social-demographic and economic indices and it is also the most compact, coherent area with the least distance to its metropolitan centre.
\end{abstract}

KEY WORDS: cities, urban areas, urban competitiveness, supraregional centres, development of the cities

ARTICLE HISTORY: received 4 February 2016; received in revised form 14 March; accepted 17 March 2016

\section{Introduction}

According to CASTELLS (1998), metropolises constitute the highest form of space organisation in the modern society and their function is based on the flow of capital, technology, knowledge and values. They are like nodes in the network of flows, concentrating social, economic, political and cultural potential. Due to this, their development is faster than that of the remaining settlement elements.

From the economic and political point of view, metropolises are the elite of the modern world. They are places where the most influential enterprises and institutions function and are concentration locations of science, culture and art. They are places focusing managerial functions and are developing the exchange of capital and goods. Due to this, metropolises also constitute a positive category in social perception. They are inherently unique, cosmopolitan, progressive and prestigious.
It comes as no surprise that cities strive to develop functionality in order to make them metropolises and to be formally awarded the status. According to this research Poland has only one metropolis included in the European network (JAtOWIECKI \& PARYSEK, 2003), namely Warsaw. At the national scale, the category of metropolis also includes other cities. Their number depends on the adopted criteria.

Białystok, Lublin and Rzeszów are the three largest cities of East Poland, capitals of provinces and centres with dominant positions in the regional network of cities. They concentrate the administrative, production, service and cultural functions of their regions. Białystok has as many as a $1 / 4$ of the inhabitants of the entire Podlaskie province. Irrespective of the unquestioned roles of leaders at the regional scale, both in scientific studies and strategic documents, these aforementioned cities usually occur separate from centres recognised as metropolises even at the national scale (compare 
JAŁOWIECKI, 2000; GORZELAK \& SMĘTKOWSKI, 2005; ILNICKI, 2003; PARYSEK, 2003). They are instead listed among the so-called potential metropolises showing certain changes which contribute to a substantial increase in their importance at a broader spatial scale, but with no clear forecast for the future.

The development of metropolitan functions of these cities is assessed differently depending on the adopted criteria. In the majority of classifications, the highest position is usually taken by Lublin (Table 1). Due to the relatively well developed control and managerial functions of Lublin and its higher academic potential, SMĘTKOWSKI ET AL. (2008) classify the city in the second class of metropolitan character, and Białystok and Rzeszów in the third class. The same order is presented by MARKOWSKI \& MARSZAE (2006). Together with Szczecin, Lublin was included in category $\mathrm{F}$ and Białystok and
Rzeszów were categorised one level lower, similar to the Bydgoszcz-Toruń agglomeration. JAŁOWIECKI (2000) applied particular demographic and economic criteria and placed Lublin together with Białystok in the group of supraregional centres and placed Rzeszów among regional centres. In the Ranking of Metropolitan Strength of Polish Cities by NORDEA METROX, conducted in 2009 by the Institute of Competitive Economy of the Regions, Rzeszów takes a higher position than Lublin and Białystok due to its stronger and more modern economy, higher quality of life and richer lifestyle of its inhabitants (following: KUć-CZAJKOWSKA, 2010). The ranking shows, however, that each of the three cities are far behind other large cities of Poland. Their metropolitan strength constitutes $4-5 \%$ of the potential of Warsaw.

Table 1. Position of Lublin, Białystok and Rzeszów in the network of Polish metropolises (author's own elaboration)

\begin{tabular}{|l|l|l|l|}
\hline \multicolumn{1}{|c|}{ Classification } & \multicolumn{1}{|c|}{ Lublin } & \multicolumn{1}{c|}{ Białystok } & \multicolumn{1}{c|}{ Rzeszów } \\
\hline Parysek, 2003 & $\begin{array}{l}\text { Potential subcontinental } \\
\text { metropolis }\end{array}$ & $\begin{array}{l}\text { Worse perspectives than those } \\
\text { for Lublin }\end{array}$ & Not mentioned \\
\hline Markowski \& Marszał, 2006 & $\begin{array}{l}\text { Potential metropolis } \\
\text { Cat. F }\end{array}$ & $\begin{array}{l}\text { Potential metropolis } \\
\text { Cat. G }\end{array}$ & $\begin{array}{l}\text { Potential metropolis } \\
\text { Cat. G }\end{array}$ \\
\hline Jałowiecki, 2000 & Supraregional centre & Supraregional centre & Regional Centre \\
\hline $\begin{array}{l}\text { Smętkowski, Jałowiecki \& } \\
\text { Gorzelak, 2009 }\end{array}$ & Regional centre of class A & Regional centre of class B & $\begin{array}{l}\text { Regional centre of class } \\
\text { B }\end{array}$ \\
\hline $\begin{array}{l}\text { Ranking of metropolitan } \\
\text { strength by NOREA } \\
\text { METROX.2009 }\end{array}$ & Position 11 & Position 11 & Position 9 \\
\hline $\begin{array}{l}\text { KPZK (Concept of Spatial } \\
\text { Management of the } \\
\text { Country) 2030 }\end{array}$ & Metropolitan centre & National centre & National centre \\
\hline
\end{tabular}

In the Concept of Spatial Management of the Country 2030, only Lublin was included in the metropolitan centres. Although at the stage of development of the Concept it failed to meet all the criteria adopted in the study, it was appreciated for the academic functions, concentration of business activity and role in contacts with countries located to the east of Poland. Białystok and Rzeszów were included in the group of national centres, with a possibility for the development of specified metropolitan functions.

\section{Materials and methods}

This paper is of an analytical and comparative character. It presents a multidimensional characteristic of the metropolitan areas: Białystok, Lublin, and Rzeszów. The assessment covered a number of elements of the social, economic and cultural environment, considered as indicators of metropolitan character in literature on the subject. First, the population potential of each of the discussed areas was analysed, including the demographic elements constituting the basis of developmental forecasts for the areas. Then, their economic activity was evaluated. The following elements were considered among others: number of business entities, structure of services, contribution of persons employed in the $R+D$ sector, presence of accommodation base in the areas, and presence of representatives of institutions and international organisations. The analysis was completed by the assessment of the cultural environment, including the cultural and sports activity of the residents. The above analyses were performed based on data obtained from the Local Data Bank of the Central Statistical Office (www.stat.gov.pl) from the period 2002-2014. Data for communities included in the studied metropolitan areas were used. Using statistical 
material at this level of detail permitted the performance of spatial analyses for each of the discussed areas and an assessment of each of the discussed areas, as well as an assessment of the intensity of particular phenomena within their boundaries. GIS software - MapInfo was used for this purpose. In addition to spatial analyses, the temporal variability of particular elements was analysed. The results allowed the formulation of conclusions regarding the permanent character of phenomena and processes.

\section{Historical overview of the development of the cities}

Lublin has the highest population of the three cities. In 2014, it had less than 350 thousand inhabitants, Białystok less than 300 thousand and Rzeszów slightly more than 180 thousand. Lublin also has the oldest history. The settlement from which the city developed was established around the $10^{\text {th }}$ century. It was awarded Magdeburg rights in 1317, but by then it was already a well developed urban mechanism. From the beginning of its history, it fulfilled the function of the leading administrative and economic centre in the region. In 1474, it became the capital of the newly designated province, called Lubelskie. The name survived until today irrespective of the course of its history.

Lublin experienced the most intensive development in the period of the reign of the Jagiellons, benefiting from the privileged location between Cracow and Vilnius. It had numerous trade privileges which permitted its development and prosperity. In 1578, it became the seat of the Crown Tribunal for the Małopolska region. After the wars of the $17^{\text {th }}$ century, the city never regained its former position. Before the outbreak of the $2^{\text {nd }}$ World War it had approximately 120 thousand inhabitants. In economic terms, it was a second category city despite being well known in Poland and abroad for its industrial plants for machine production and food processing. As a result of the war, the city lost 40 thousand inhabitants, as well as considerable parts of its buildings and technical infrastructure which became the target of attacks by the German army already in the first days of September 1939. From July 1944 to January 1945, Lublin served as the capital of Poland. It also hosted the celebration of the $10^{\text {th }}$ anniversary of the People's Republic of Poland. This provided the city with substantial assistance to repair war damage. Almost throughout the period of the People's Republic of Poland, Lublin was a city of serious industrial investment which became the driving force for the rapid development of the population. In the period from 1945 to 2005, the number of permanent residents of the city increased more than four times.

Rzeszów also dates back to medieval times, although somewhat later than Lublin. Awarding the city rights in 1354 was just the beginning of the city's development. Until 1845, Rzeszów was a private city, belonging, among others, to the Lubomirski family. Located in the peripheries of the Habsburg Monarchy, with centres such as Lvov, Przemyśl, Biecz, Sanok, Krosno, or Jarosław in its vicinity, it developed slowly. It achieved the role of a supraregional centre only in the second half of the $19^{\text {th }}$ century, when it became the seat of the administration and judicature and gained a railway connection with Cracow and Lvov. The true development of Rzeszów, however, took place in the period of the $2^{\text {nd }}$ Republic of Poland, in relation to the construction of the Central Industrial District. The city appeared on the map of important investments. Państwowe Zakłady Lotnicze (State Aviation Enterprise) and a branch of the factory of H. Cegielski from Poznań producing anti-aircraft canons were established here. The successful industry was beneficial for the city's development. In 1939, Rzeszów had 43 thousand inhabitants. During the war, however, it lost $1 / 3$ of its population, as well as part of its building infrastructure, including the historical part of the city. After the $2^{\text {nd }}$ World War, the city was designated as the provincial capital, which largely strengthened its development potential. A factor favouring the development of Rzeszów was the presence of many plants connected with the machine, metal and chemical industries. These economic investments were the driving force of both the population and spatial development in the city.

In recent years, the location of Rzeszów in the transport network has become an important factor in its development. It is located on the junction of road and railway routes of international importance. They include, among others, the III Paneuropean Transport Corridor (road and railway) connecting West Europe with Ukraine. Motorway A4 is currently under construction. National road No. 19 also runs through the city, connecting the Baltic states with South Europe. Good transport accessibility favours new economic and cultural investments.

Białystok is the youngest of the cities discussed here. Its origin dates back to the end of the $17^{\text {th }}$ century. It began its existence as the residence of Stefan Branicki and was successively expanded and improved by subsequent owners. In the $18^{\text {th }}$ century, it became a cultural centre well known 
in Poland. In 1796, Białystok became the capital of an administrative unit for the first time. This offered new perspectives and chances for development. Another factor in its development was the construction of the railway connecting Warsaw and St. Petersburg and the establishment of textile and clothing industrial plants in Białystok resulting from the high demand for clothing articles in the Russian market. At the end of the $19^{\text {th }}$ century, 300 industrial plants functioned there, employing a total of 5 thousand people. Białystok earned its description of the Manchester of the North. In 1915, however, a major part of the industrial and transport infrastructure was destroyed as a result of the war.

The textile industry was reconstructed very slowly over the entire inter-war period of 20 years. The city became the third largest centre for the textile industry in Poland. The events of the $2^{\text {nd }}$ World War, however, caused the destruction of $75 \%$ of the infrastructure of the city. Losses of the population were also considerable. Only 47 thousand out of more than 100 thousand inhabitants survived. Białystok experienced the largest losses during the $2^{\text {nd }}$ World War of these described cities.

In the 1950s and 1960s, many industrial plants were established in Białystok representing different areas of the economy, from the traditional textile industry, through wood processing, construction and food production, to the electromachinery industry. In 1961, the city already had 120 thousand inhabitants. In total, in the years 1945-2005, the population of Białystok increased more than six times.

\section{Metropolitan aspirations of Lublin, Białystok and Rzeszów}

Irrespective of the scientific discussion and economic reality, Lublin, Białystok, and Rzeszów all show metropolitan aspirations. They all belong to the Union of Polish Metropolises (UMP) which includes the 12 largest cities in Poland and to the Eurocities network, associating them with the large cities of the majority of European countries. In 2008, after the presentation by the Ministry of Home Affairs and Administration of a draft of the socalled metropolitan act, authorities of each of the three cities submitted a petition for including them in the list of metropolitan areas of Poland. The petition, approved by the Union of Polish Metropolises, had a positive effect. Białystok also undertook efforts to be included in the list of Polish metropolises in 2012, after the announcement of the Concept of the Spatial Management of the Country 2030. The letter was addressed directly to the Prime Minister and Government of the Republic of Poland and included a well justified request for recognising the city as a metropolitan centre (www.bialystok.gazeta.pl).

Irrespective of activities conducted at the central level, based on partner arrangements with authorities of the neighbouring districts, all of the described cities led to the appointment of metropolitan areas of which they became the main centres. The Lublin Metropolitan Area (LMA) and Rzeszów Metropolitan Area (RMA) were established in 2005, and the Białystok Metropolitan Area (BMA) in 2009. The objective of this study is to compare the cities themselves, as well as the metropolitan areas established around them in terms of parameters constituting metropolitan attributes.

\section{Population potential}

All of the three metropolitan areas exceed the population of 500000 , considered to be the threshold value for metropolises. The Rzeszów Metropolitan Area is the most populated, although its centre, i.e. Rzeszów, has only 183000 inhabitants. This relatively low population is compensated by high indices for the neighbouring districts. The second position is taken by the Lublin Metropolitan Area with a number of inhabitants similar to that of Rzeszów. The Białystok Metropolitan Area is the least populated of the three. It is also an area with an extremely low mean population density which is below the national average (Table 2).

The analysis of the population distribution in each of the three areas suggests that the Rzeszów metropolitan area is the most uniform in these terms. No communities with extremely low population density below 50 people $/ \mathrm{km}^{2}$ occur here. Such communities, however, are present in the case of the two remaining areas. In the Białystok Metropolitan Area, such a situation concerns a considerable majority of communities. Except for several larger centres, the majority of administrative units show a population density below 50 people $/ \mathrm{km}^{2}$. Only several communities directly neighbouring Białystok show values of 50-100 people $/ \mathrm{km}^{2}$. In the case of the Lublin Metropolitan Area, a classic concentric system occurs, where the population density decreases with growing distance from the central city. In the close vicinity of Lublin, the population density amounts to 100150 people $/ \mathrm{km}^{2}$, decreasing with growing distance to 50 people $/ \mathrm{km}^{2}$ in the peripheral communities. Such communities, however, are in the minority (Fig. 1). 
Table 2. Descriptions of the metropolitan areas of Lublin, Białystok and Rzeszów (2014) (author's own elaboration based on data of the Central Statistical Office, www.stat.gov.pl)

\begin{tabular}{|l|l|l|l|}
\hline \multicolumn{1}{|c|}{ Features } & \multicolumn{1}{|c|}{ BMA } & \multicolumn{1}{c|}{ LMA } & \multicolumn{1}{c|}{ RMA } \\
\hline Area of the metropolitan area & $5132 \mathrm{~km}^{2}$ & $4221 \mathrm{~km}^{2}$ & $4329 \mathrm{~km}^{2}$ \\
\hline $\begin{array}{l}\text { Population of the metropolitan } \\
\text { area }\end{array}$ & 510749 & 712124 & 765157 \\
\hline $\begin{array}{l}\text { Mean population density in the } \\
\text { metropolitan area }\end{array}$ & 100 people $/ \mathrm{km}^{2}$ & 169 people $/ \mathrm{km}^{2}$ & 177 people $/ \mathrm{km}^{2}$ \\
\hline Area of the central city & $102 \mathrm{~km}^{2}$ & $147 \mathrm{~km}^{2}$ & $117 \mathrm{~km}^{2}$ \\
\hline Population of the central city & 295459 & 341722 & 185123 \\
\hline $\begin{array}{l}\text { Population density in the central } \\
\text { city }\end{array}$ & 2883 people $/ \mathrm{km}^{2}$ & 2317 people $/ \mathrm{km}^{2}$ & 1591 people/km² \\
\hline $\begin{array}{l}\text { Districts included in the } \\
\text { metropolitan area }\end{array}$ & $\begin{array}{l}\text { city of Białystok } \\
\text { Białostocki } \\
\text { Sokólski }\end{array}$ & $\begin{array}{l}\text { city of Lublin } \\
\text { Lubelski } \\
\text { Lubartowski } \\
\text { Łęczyński } \\
\text { Świdnicki }\end{array}$ & $\begin{array}{l}\text { city of Rzeszów } \\
\text { Rzeszowski } \\
\text { Kolbuszowski } \\
\text { Łańcucki } \\
\text { Ropczycko-Sędziszowski } \\
\text { Strzyżowski } \\
\text { Dębicki }\end{array}$ \\
\hline
\end{tabular}

Also in terms of natural population growth, the best situation is recorded in the Rzeszów Metropolitan Area. In the majority of its communities, the value of the parameter is positive. Even when it is negative, it takes values of up to $-2 \%$ (Fig. 2). The analysis of the dynamics of natural population growth collectively for the entire area shows that it was positive over the last decade (Fig. 3). Should this tendency be maintained, the population of the area is very likely to continue increasing. In the Białystok Metropolitan Area, natural population growth is negative in the majority of the area, whereas it should be emphasised that over the entire eastern zone along the border with Belarus, it reaches values of $-5--15 \%$ (Fig. 2). Such a situation also occurs in several communities in the western part of the country. Moreover, the total natural population growth for each year of the last decade was negative here. Data show no positive changes in the scope. It is not certain whether the Białystok Metropolitan Area will be able to maintain the current number of inhabitants.

In the Lublin Metropolitan Area, the demographic situation is also unfavourable. Natural population growth is negative in the majority of communities, although the values are not as low as in the previous case. The south-eastern part of the area with a population growth below $-5 \%$ belongs to a group of areas under serious demographic threat. In the period 2002-2013, total values of natural growth were negative (Fig. 3), although from 2006, a slight improvement of the situation was recorded. The demographic situation of the Lublin Metropolitan Area is therefore uncertain.
Migrations constitute an important element determining the population resources of a given area. Each of the analysed areas showed a positive migration balance in the last decade (Fig. 4). The central cities of the areas showed variable values in this aspect. In Białystok and Lublin, the balance for each year of the last decade was negative and in Rzeszów from 2007 - positive. It is the only one of the three analysed cities showing prevalence of immigration over emigration in the study period. This, however, may be related to the expansion of the administrative boundaries of the city, resulting in the incorporation of suburban communities with positive migration balance due to the suburbanisation processes. Nonetheless, the Rzeszów Metropolitan Area has the best demographic situation among all of the three analysed areas. The processes occurring in the area are of progressive character.

In terms of the spatial variability of migration phenomena, the analysed areas evidently represent separate types (Fig. 5). In the case of the Białystok Metropolitan Area, the suburban zone clearly stands out. In communities directly surrounding Białystok, the migration balance is positive and relatively high, exceeding $10 \%$. In the remaining area, the balance is negative, showing an extremely low value in the Dąbrowa Białostocka community reaching $-12 \%$. In the case of Lublin, the situation is similar, although the suburban zone is not so uniform in terms of migration balance values. This suggests slower and more spatially variable dynamics of suburbanisation. Moreover, a lower number of communities show a negative balance. In the Rzeszów Metropolitan Area, the situation is 
completely different. The zone of positive migration balance around the central city is more extensive and less distinguishable in terms of values of the balance. Moreover, its western part includes an area of positive migration balance, not related to the direct influence of Rzeszów. The amplitude of migration balance values in the Rzeszów Metropolitan Area are lower than in the Białystok and Lublin Metropolitan Areas. The level of the phenomenon of migration is more uniform here.

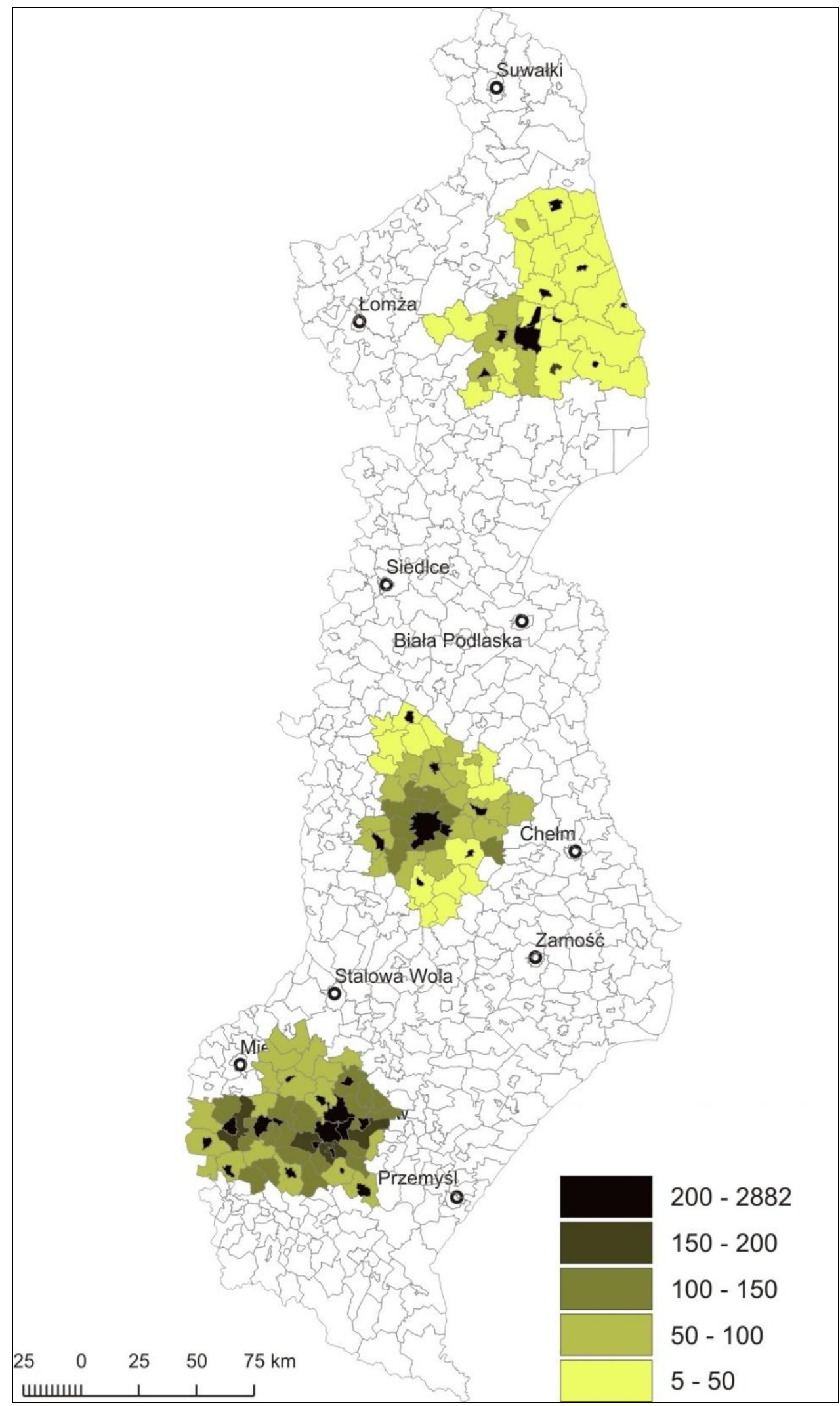

Fig. 1. Population density in the Białystok, Lublin and Rzeszów Metropolitan Areas (2014) (author's own elaboration based on data from the Local Data Bank of the Central Statistical Office) 


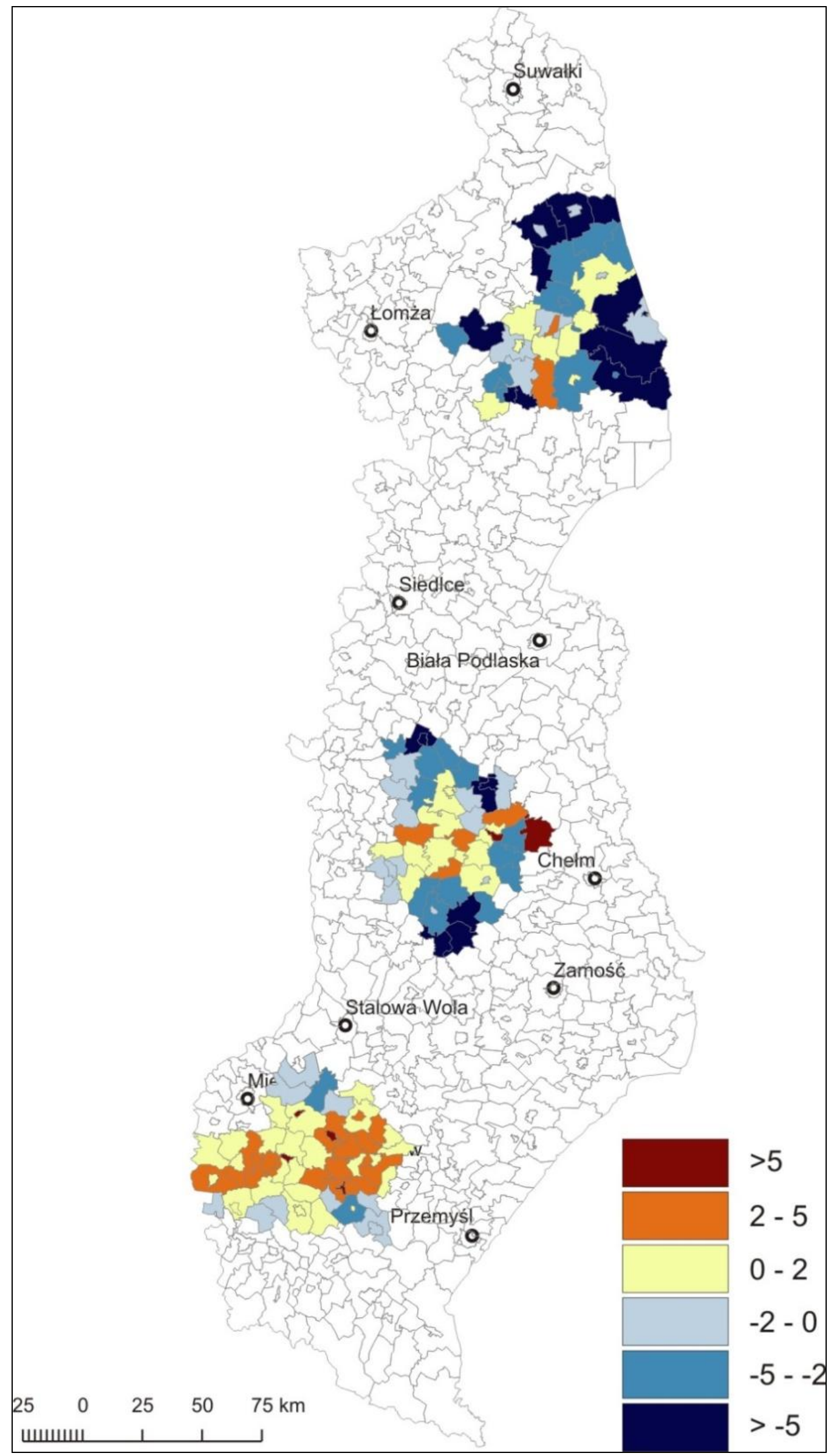

Fig. 2. Natural population growth in the Białystok, Lublin and Rzeszów Metropolitan Areas (\%o 2014) (author's own elaboration based on data from the Local Data Bank of the Central Statistical Office) 


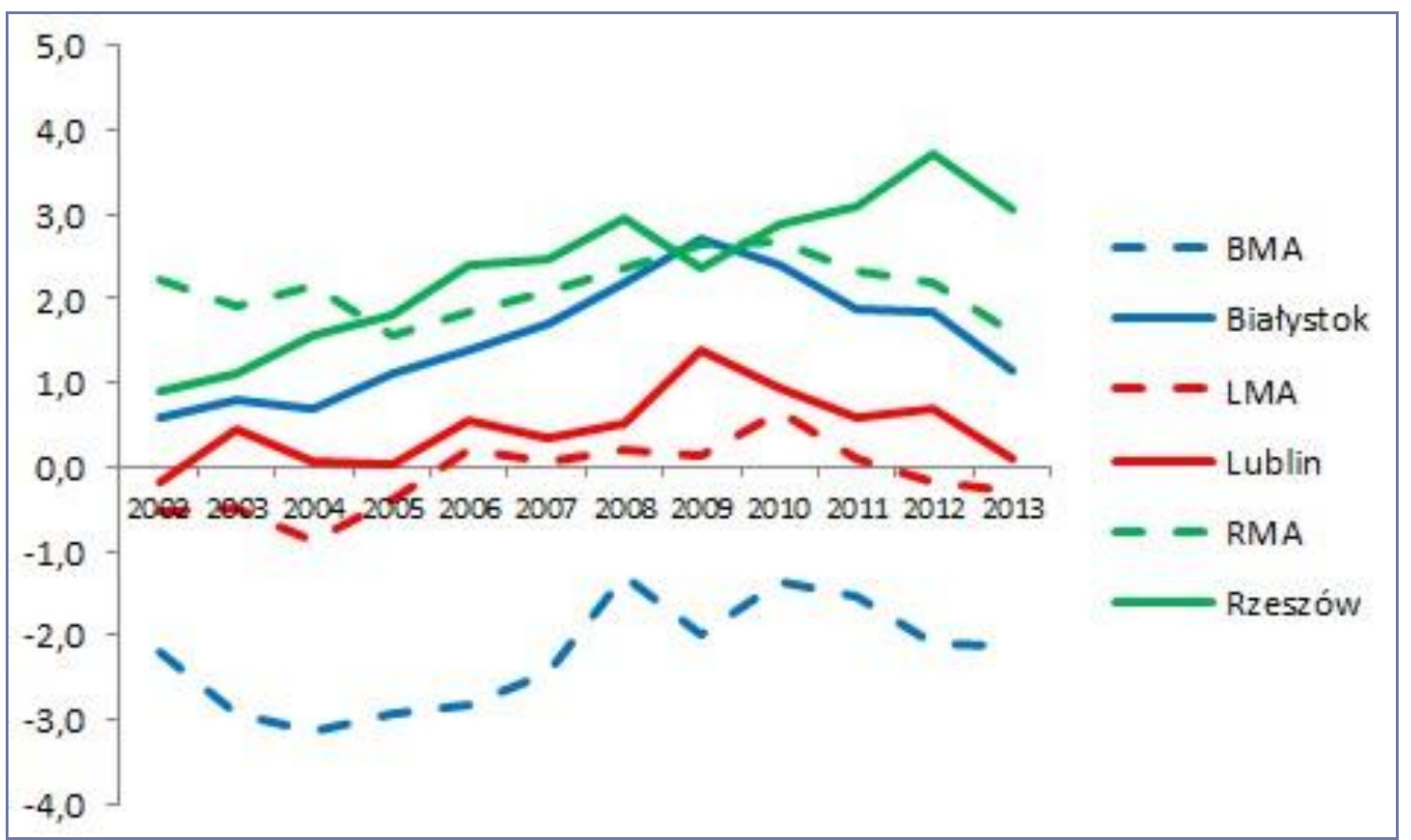

Fig. 3. Dynamics of natural population growth in the Białystok, Lublin and Rzeszów Metropolitan Areas (2002-2013) (author's own elaboration based on data from the Local Data Bank of the Central Statistical Office)

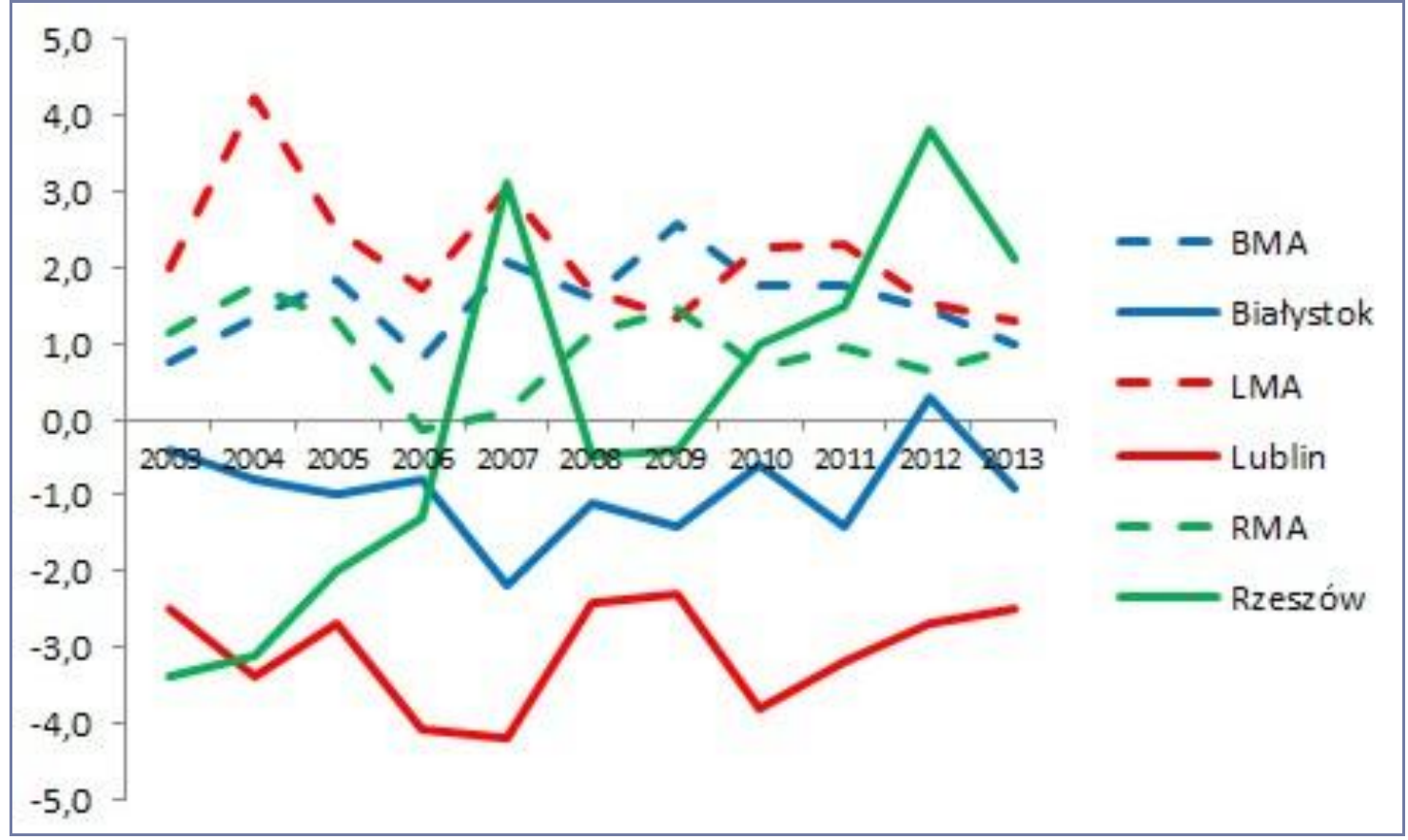

Fig. 4. Migration balance per 1000 people in the Białystok, Lublin and Rzeszów Metropolitan Areas (2002-2013) (author's own elaboration based on data from the Local Data Bank of the Central Statistical Office)

As a consequence of differences in the scope of natural population growth and migrations, the analysed areas show a diverse age structure of their populations. The most favourable structure occurs in the case of the Rzeszów Metropolitan Area, where the contribution of the post-productive group is relatively low (16.5\%), and that of the pre-productive one is high $(20.3 \%)$. The Lublin Metropolitan Area has a similar structure. In the Białystok Metropolitan Area, the contribution of people at post-productive age is higher (18.1\%) than those at pre-productive age (16.9\%). A somewhat different hierarchy is obtained based on the analysis of the age structure of the central cities themselves. The worst situation occurs in Lublin, because the contribution of the pre-productive group is lower than that of the post-productive group here. In the two remaining cities, although the proportions are similar, the difference between the categories mentioned is lower. 


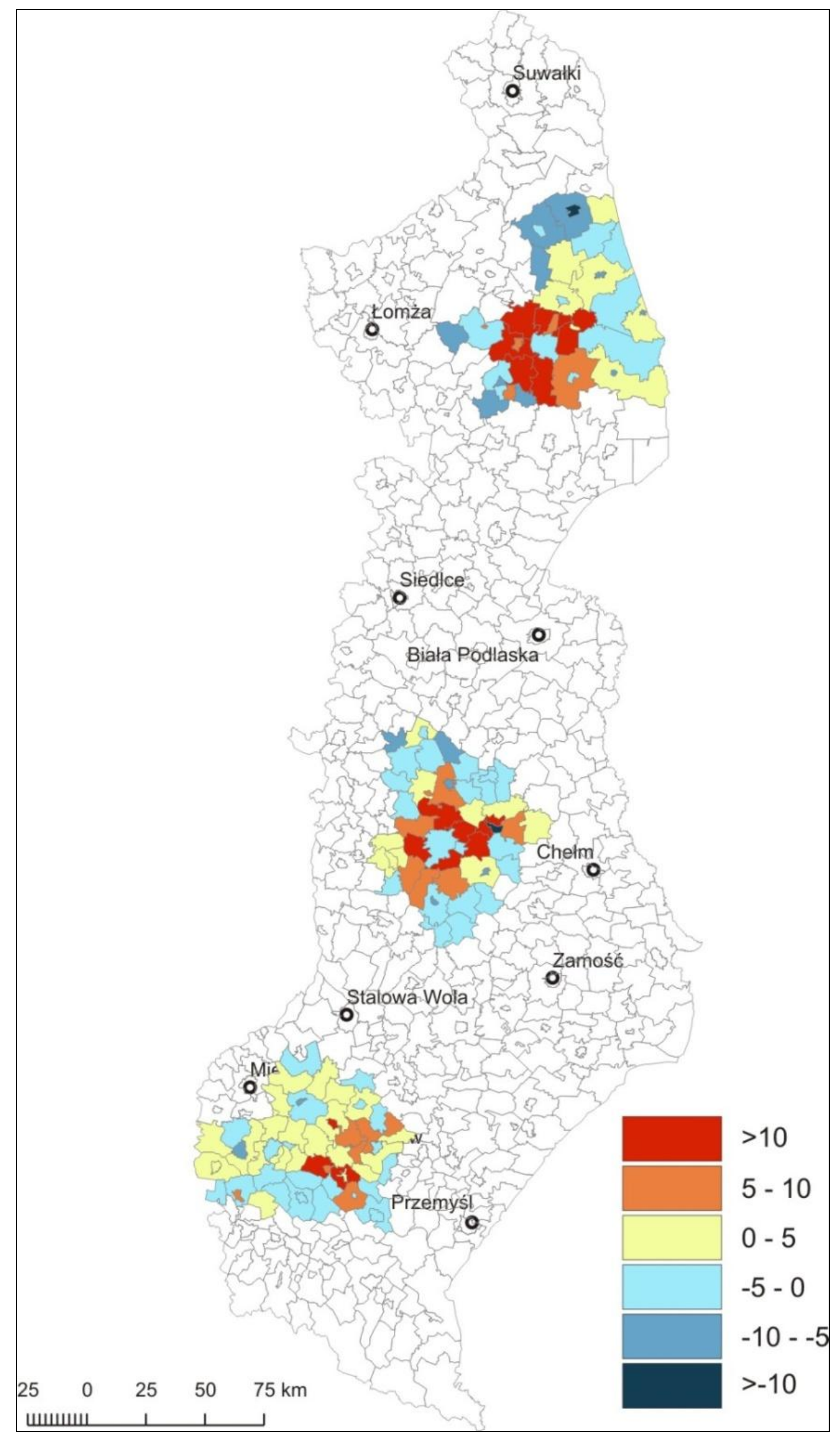

Fig. 5. Migration balance per 1000 people in the Białystok, Lublin and Rzeszów Metropolitan Areas (2014) (author's own elaboration based on data of the Local Data Bank of the Central Statistical Office) 


\section{Business activity}

The scale of entrepreneurship is a factor strongly contributing to economic development. The number and structure of business entities providing activity in a given space provides information on the social capital of the population, because business entities appear and function in a market only in the case of demand for certain categories of goods and services, and when they are managed by groups of skilled people willing to organise specified types of enterprises. In 2014, the highest number of entities registered per 10 thousand people was recorded in Rzeszów (1341), slightly less in Lublin (1272), and the least in Białystok (Fig. 6). The comparison of the level of entrepreneurship in metropolitan areas with mean values for Poland shows, however, that none of the metropolitan areas reaches the mean value (mean for Poland 1071). The lowest indices are recorded for the Białystok Metropolitan Area. The number of entities entered in the business registry REGON per 10 thousand inhabitants here is four times lower than the mean value for Poland.

The distribution of enterprises is not uniform. The highest number of entities per 10 thousand inhabitants is located in cities and their direct vicinity (Fig. 7). In the case of the Białystok and Lublin Metropolitan Areas, a classic metropolitan system occurs, where the number of enterprises considerably decreases with growing distance from the centre. Due to the benefits of agglomerations, business activity shows evident tendencies for concentration in the central city and its direct vicinity. The process causes diversification of space into areas of growth and peripheral areas. In the case of the Rzeszów Metropolitan Area, several spatially dispersed centres of entrepreneurship are distinguishable. In economic terms, the position of Rzeszów is not as dominant as that of Lublin and Białystok.

Due to their role for their surroundings, metropolises should be places of concentration of services of a higher level. Such services include the aforementioned higher education, culture and art, but also specialised medical services, or services related to economy and state management. Metropolises should be centres particularly featuring specialised services, especially in the scope of business. Such services include finance, insurance, consulting, advertising, logistic centres and $\mathrm{R}+\mathrm{D}$ centres. In such terms, Lublin stands out among the cities analysed. In 2013, approximately 16 thousand entities providing higher level services functioned there, whereas in ystok the number amounted to 12 thousand, and in Rzeszów to 10 thousand. The structure of this type of services in the area of the metropolises analysed is similar. In each of the three centres, the highest contribution is reached by services related to professional, scientific and technical activity, followed by health care and social welfare and education. In Białystok, services in the scope of administration reach a somewhat lower contribution (Fig. 8).

Analysis of data concerning the number of newly registered entities in the decade analysed (2003-2013) shows that until 2011, the processes of entrepreneurship were of a similar character both in metropolitan areas and the centres themselves (Fig. 9). After the exceptionally unfavourable year 2011, with a considerable decrease in the number of newly registered enterprises, substantial progress was recorded in Lublin and the Lublin Metropolitan Area and further regress in Białystok and the Białystok Metropolitan Area.

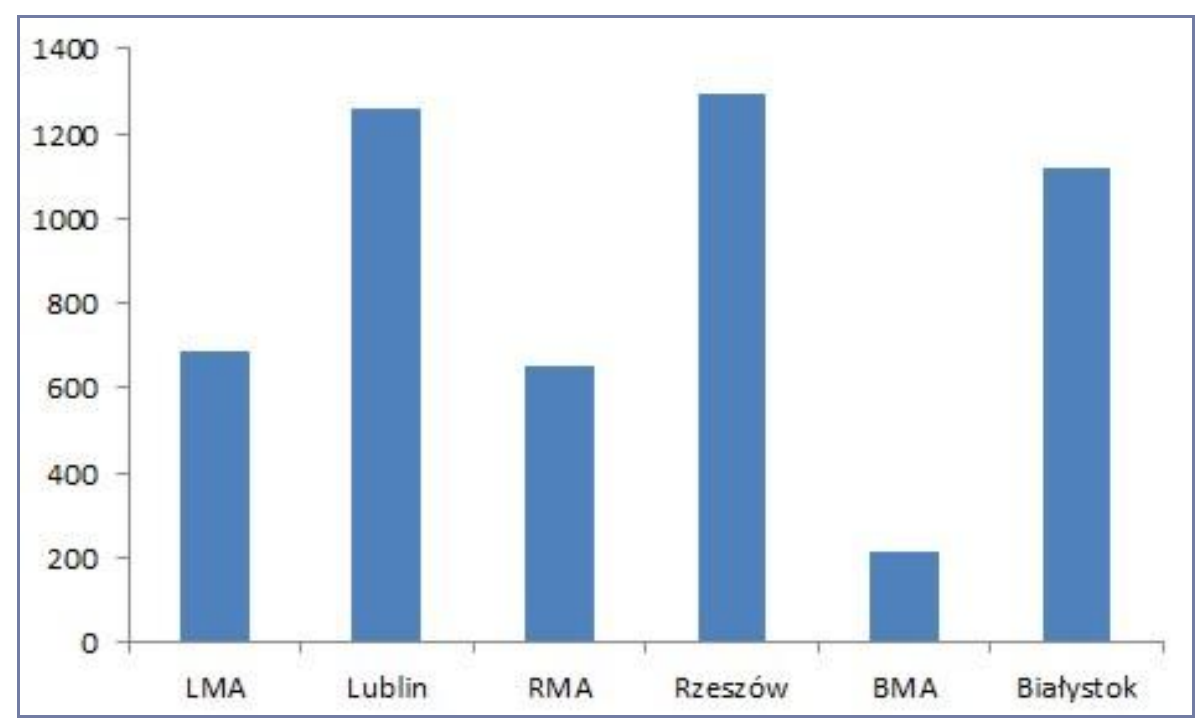

Fig. 6. Entities entered in the business registry REGON per 10 thousand inhabitants (2014) (author's own elaboration based on data from the Local Data Bank of the Central Statistical Office) 


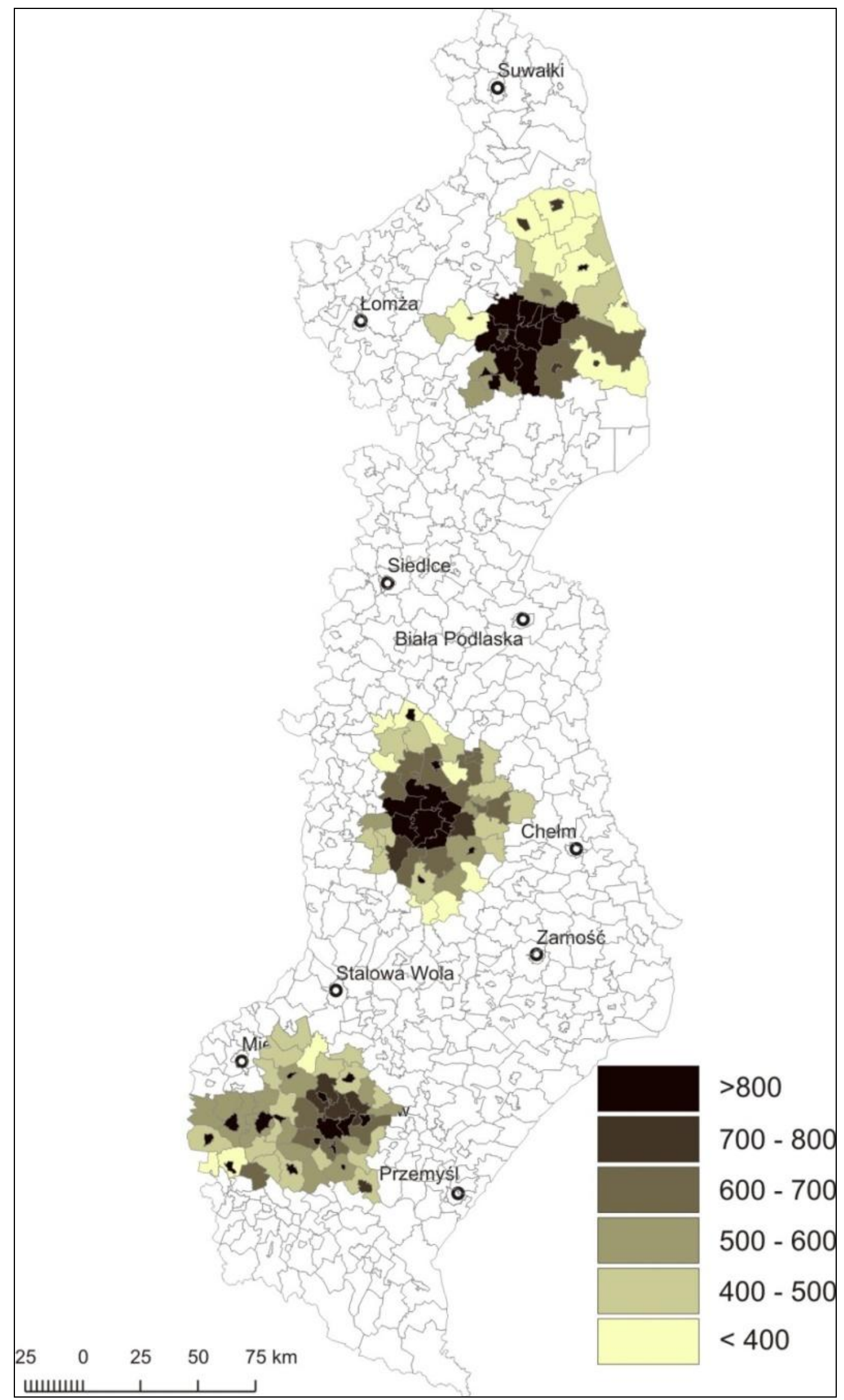

Fig. 7. Entities entered into the business registry REGON per 10 thousand inhabitants (2014) (author's own elaboration based on data of the Local Data Bank of the Central Statistical Office) 


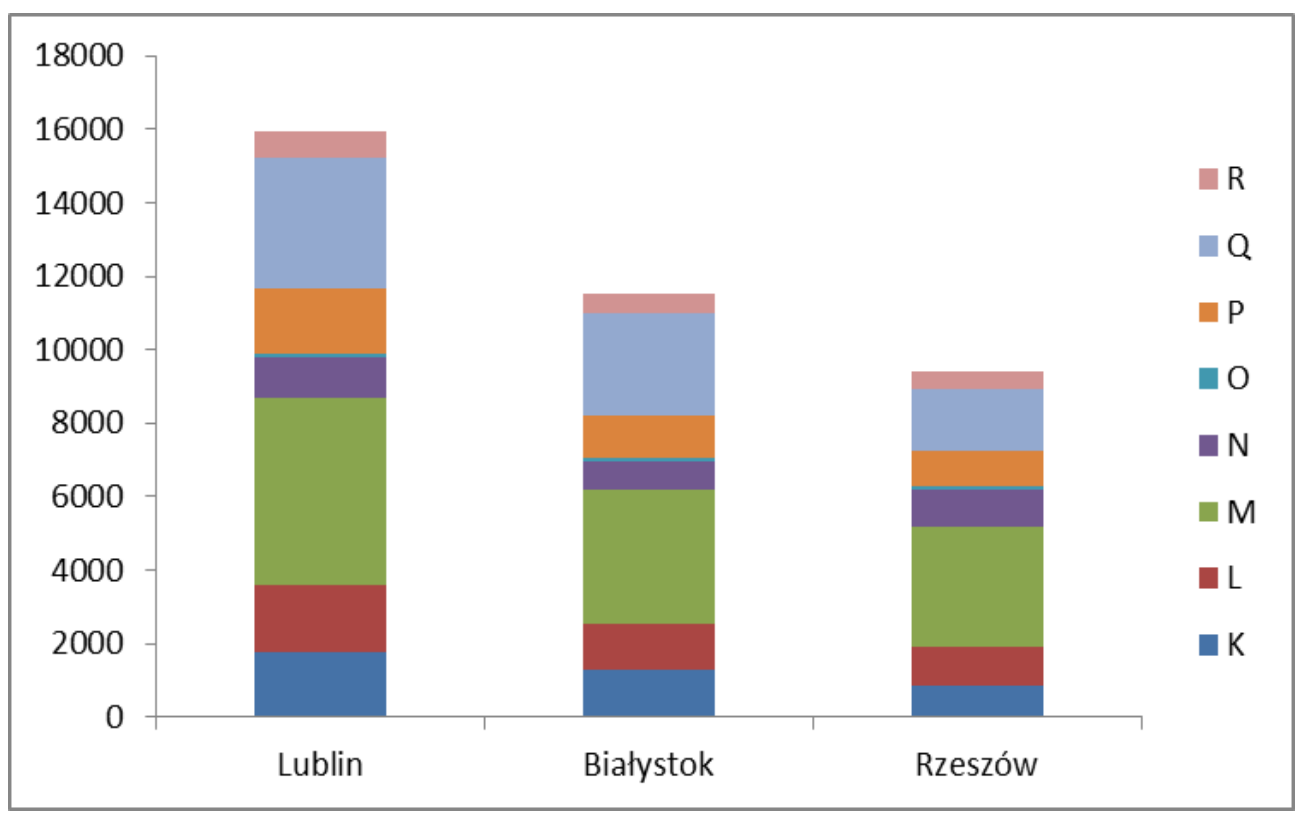

Fig. 8. Services of a higher level in the Białystok, Lublin, and Rzeszów (2014)

(author's own elaboration based on data of the Local Data Bank of the Central Statistical Office)

$\mathrm{R}$ - Activity related to culture, entertainment and recreation; Q - Health care and social welfare; P - Education; O - Public administration and national defence; $\mathrm{N}$ - Activity in the scope of administration services and supporting activity; $\mathrm{M}$ Professional, scientific, and technical activity

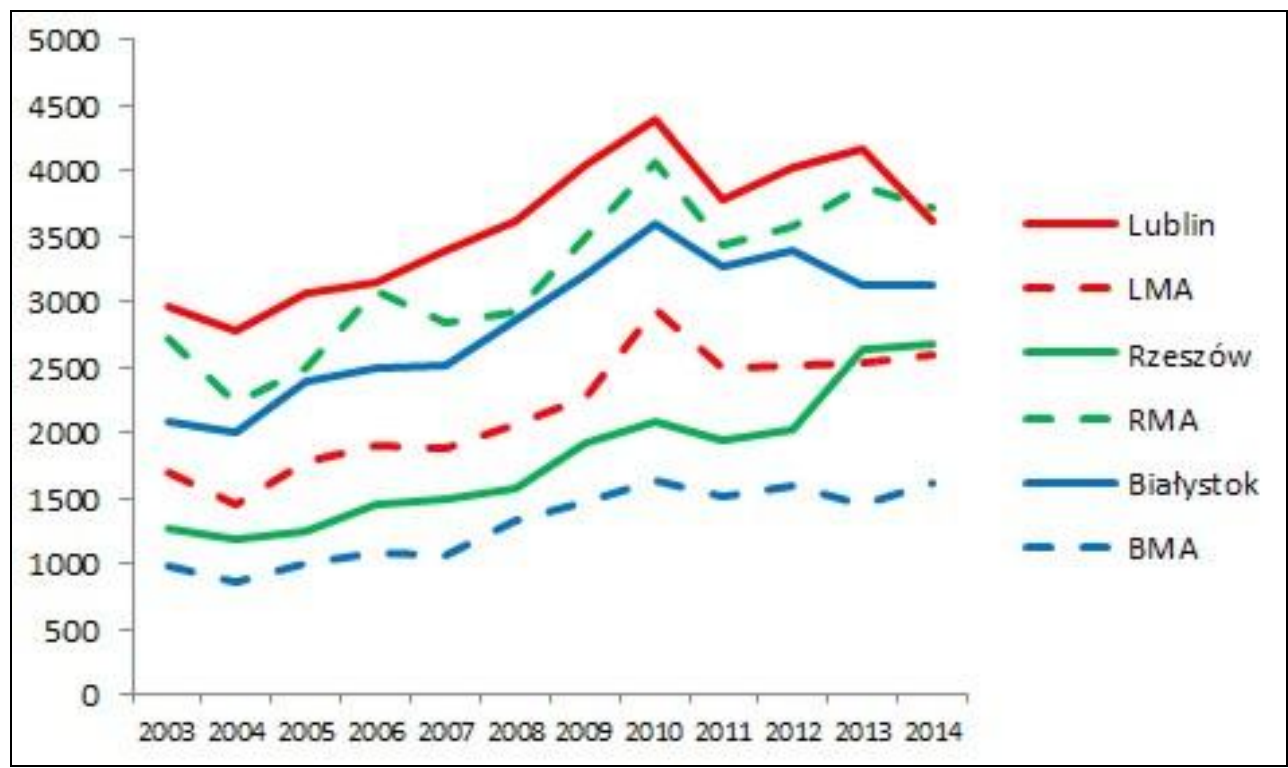

Fig. 9. Entities newly registered in the REGON system

(author's own elaboration based on data of the Local Data Bank of the Central Statistical Office)

From the moment of transition of the economy from centrally planned to market economy, factors related to the availability of innovation and capital, as well as to the presence of research and development institutions, become increasingly important for economic development. Only the development of science combined with that of human capital guarantees the competitiveness of particular regions. It is also one of the indicators of metropolitan character. All of the metropolitan areas analysed include research and development institutions, usually dependent on the existing schools of higher education. New research centres were established in them with the contribution of resources obtained from EU funds. In Podkarpackie province in 2011, the highest level of contribution of enterprises financing research and development works was reached (NAUKA I TECHNIKA, 2011). Nonetheless, the contribution of employees of the $\mathrm{R}+\mathrm{D}$ sector working collectively in each of the areas analysed is inconsiderable. In the Podkarpackie province it amounts to $0.77 \%$, Lubelskie $0.68 \%$, and Podlaskie $0.53 \%$ (LOCAL DATA BANK OF THE CENTRAL STATISTICAL OFFICE, 2011). The contribution of entities from the research and development sector in the total number of business entities is also 
relatively low. In Rzeszów, it amounts to 36\%, in Lublin to $35.8 \%$, and in Białystok to $33.2 \%$. The cited values show that none of the discussed areas belongs to regions with leading importance in the research and development sector. It should be emphasised, however, that Rzeszów and the Rzeszów Metropolitan Area take the leading position in the analysed group, showing a slight prevalence over Lublin and the Lublin Metropolitan Area. The last position is occupied by Białystok and the Białystok Metropolitan Area.

The importance of metropolises can be measured by the number of international institutions reflecting the importance of the area at the international scale. Lublin is the unquestioned leader in these terms. It hosts the Consulate General of Ukraine and Honorary Consulates of: Brazil, Germany, France and Great Britain. Białystok is the seat of the Consul General of Belarus and two Honorary Consulates: of Romania and Croatia. Only three Honorary Consulates function in Rzeszów: that of Ukraine, Republic of Slovakia and Germany.

Tourism has become an important branch of economic activity in recent years. The chances for development of tourism are offered by the natural environment as well as the multicultural heritage. According to the definition by GAWORECKI (2007), tourist values include tourist goods generating demand for tourism. Therefore, they determine the spatial directions of tourist traffic, and determine its rate and seasonal structure. Tourist values are the primary force attracting tourists to a specified place. Therefore, they are considered as one of the factors for regional development, and in the case of urban areas also factor of metropolisation. Appropriately conducted tourism policy and promotion of tourist products also offer a chance of high benefits from the tourist potential inherent in the metropolitan areas.

Each of the three metropolitan areas analysed implements an active tourist policy. They continuously develop the list of tourist products, taking care of their original and unique character. From 2013, Lublin has a sector-based strategy for tourism development by 2025 specifying the assumptions and means of development of the sector in the area of the city in the specified time horizon. The document was prepared based on order of the Lublin Municipal Office. Also Rzeszów is attempting to prepare a formal strategic document determining the direction of tourism development in its area in a professional manner. In 2013, a competition was announced for the preparation of the Strategy of tourism development in Rzeszów by 2020 . In the middle of 2015, however, the project was still not developed. In the case of
Białystok, the situation is somewhat different the development of the tourist sector was included as a part of the general Strategy of Development of Białystok for the years 2011-2020.

In terms of hotel accommodation, in both quantitative and qualitative terms, the Rzeszów Metropolitan Area and Rzeszów are in the lead. In the entire Rzeszów Metropolitan Area, 77 of the hotels were registered in 2014, including only 33 in Rzeszów. They include one five-star hotel, as many as six four-star hotels and nine threestar hotels. In the Lublin Metropolitan Area, the total number of hotels is considerably lower, amounting to 44 . The majority of them, as many as 25 , are located in the central city, i.e. Lublin (Table 3). They include one five-star hotel, three four-star hotels and 15 three-star hotels. In the Białystok Metropolitan Area, the number of hotels is the lowest - 37 in total, including 21 in Białystok. Only seven of them belong to the three highest categories: these are two four-star hotels, and five three-star hotels. No five-star hotels are recorded here. According to the above data, the Rzeszów Municipal Area is distinguished among each of the analysed areas not only by the highest number of hotels and the highest number of ones with the highest standard, but also by the fact that the majority of hotels are located outside the central city. Some of them are located in the suburban area of Rzeszów, but a high number of hotels also occur in the Dębicki district.

The picture becomes somewhat more complicated in the case of comparison of the number of people using the accommodation offered in the aforementioned hotels and their occupancy. In general, the highest numbers of tourists are accommodated in the Rzeszów Metropolitan Area. In its area together with the central city in 2014, hotel accommodation was used by approximately 320 thousand people. It seems to partly result from the convenient location of Rzeszów in the transport network. The presence of an international airport with flight connections to various regions of Europe and location on the route of the III Paneuropean Transport Corridor, i.e. European route E40 (national road No. 4) running from France through Belgium, Germany, Poland, Ukraine, Russia to Kazakhstan, results in an inflow of people from abroad, also for business purposes. The Białystok Metropolitan Area is second in terms of the number of tourists, with 280 thousand tourists, followed by the Lublin Metropolitan Area with approximately 250 thousand tourists. In terms of the total number of accommodation places sold, the Rzeszów Metropolitan Area is also the leader (450 thousand). The Lublin and 
Białystok Metropolitan Areas have almost equal positions with the number of accommodation places used at a level of 370 thousand. Considering exclusively the central cities, the highest values are recorded for Lublin, and lower for Rzeszów, followed by Białystok. It is evident that in tourist terms, Lublin has a more dominant position in relation to its metropolitan area than Rzeszów and Białystok. The highest numbers of foreign tourists are attracted to the Białystok Metropolitan Area, far exceeding the numbers for the Rzeszów and Lublin Metropolitan Areas. This prevalence is particularly evident in the case of comparisons of the central cities. In Białystok, foreign tourists constitute more than $40 \%$ of all tourists, but in Lublin less than $30 \%$. Such high popularity of Białystok among foreign tourists partly results from the unique environmental values of the entire region of Podlasie, for example the Białowieska Forest. Białystok, as its capital, constitutes a starting point for trips to various places in Podlasie.

Table 3. Accommodation base in the Białystok, Lublin and Rzeszów Metropolitan Areas (2014) (author's own elaboration based on data of the Local Data Bank of the Central Statistical Office)

\begin{tabular}{|l|c|r|r|r|r|c|}
\hline & $\begin{array}{c}\text { Total number of } \\
\text { hotels }\end{array}$ & Rooms & $\begin{array}{c}\text { Resident guests } \\
\text { (Poles) }\end{array}$ & $\begin{array}{c}\text { Accommodation } \\
\text { places sold to } \\
\text { residents } \\
\text { (Poles) }\end{array}$ & Foreign tourists & $\begin{array}{c}\text { Accommodation } \\
\text { places sold to } \\
\text { foreign tourists }\end{array}$ \\
\hline Lublin & 25 & 1276 & 146920 & 227825 & 55538 & 80594 \\
\hline LOM & 19 & 331 & 33733 & 52523 & 5181 & 7705 \\
\hline Rzeszów & 33 & 1283 & 137456 & 207473 & 50197 & 67439 \\
\hline ROM & 44 & 1098 & 95518 & 159978 & 16773 & 24949 \\
\hline Białystok & 21 & 923 & 121591 & 162887 & 88859 & 110325 \\
\hline BOM & 16 & 513 & 55479 & 77801 & 15415 & 18015 \\
\hline
\end{tabular}

For the purposes of comparison of the different levels of metropolisation of the areas analysed, the cultural offerings of their centres was analysed also in the terms of cultural activity. Numerical data show that in terms of the number of theatres and opera houses, all three cities are at a similar level with the slight dominance of Lublin, where there are 6 such institutions, whereas Białystok features 5, and Rzeszów 3 (Table 4). Considering the fact that the numbers are relatively low, the variability between the cities in this kind of activity is not high, although a lower position of Rzeszów is evident. In terms of the number of staged performances, the variability is somewhat higher, and the order is different. Białystok takes the highest position. The last position is taken by Rzeszów with half as many performances as Białystok. The same order is observed in the case of comparison of the number of participants of staged performances: Białystok remains the leader, with Lublin on the second place, followed by Rzeszów. The leading role of Białystok results from the function of the Opera and Podlasie Philharmonics commissioned in 2012. It is the largest artistic institution in NE Poland, and one of the most modern artistic institutions in this part of Europe. The performances attract not only the inhabitants of the city, but also the surrounding regions.

Table 4. Philharmonics and theatres in Białystok, Lublin, and Rzeszów (2014) (author's own elaboration based on the Local Data Bank of the Central Statistical Office)

\begin{tabular}{|l|c|c|c|c|c|c|c|c|c|}
\hline & \multicolumn{3}{|c|}{ Number of objects } & \multicolumn{3}{c|}{ Performances } & \multicolumn{3}{c|}{ Audience } \\
\cline { 2 - 12 } & Białystok & Lublin & Rzeszów & Białystok & Lublin & Rzeszów & Białystok & Lublin & Rzeszów \\
\hline Philharmonics & 1 & 1 & 1 & 45 & 42 & 97 & 14818 & 14535 & 36150 \\
\hline Dramatic theatre & 1 & 3 & 1 & 248 & 296 & 307 & 29200 & 48503 & 41035 \\
\hline $\begin{array}{l}\text { Musical } \\
\text { entertainment theatre }\end{array}$ & 0 & 1 & 0 & - & 94 & - & - & 27636 & - \\
\hline Opera theatre & 1 & 0 & 0 & 192 & - & - & 101497 & - & - \\
\hline Puppet theatre & 2 & 1 & 1 & 447 & 360 & 177 & 44357 & 38834 & 25012 \\
\hline Total & 5 & 6 & 3 & 932 & 792 & 581 & 189872 & 129508 & 102197 \\
\hline
\end{tabular}


In terms of the number of mass events, the Lublin Metropolitan Area, and particularly Lublin, dominates the discussed areas (Fig. 10). The large majority of events of this type are held in the central city of the Lublin Metropolitan Area. In 2014, the city held more than 120 mass events with approximately 50 in the remaining communities of the metropolitan area. The large majority of them were sports events. This is related to the popularity of the Globus sports hall which hosts many sports events of national importance, particular in basketball, boxing and kick-boxing. In 2014, a new municipal football stadium was commissioned with a capacity of 15,000 people. The city is, therefore, offered a possibility of expanding its sports offering within the supraregional range. The advantage of Lublin over the remaining two regions is very evident. The position of metropolitan areas, however, is relatively equal, although the Białystok Metropolitan Area has a considerably poorer position only offering approximately 15 events annually.

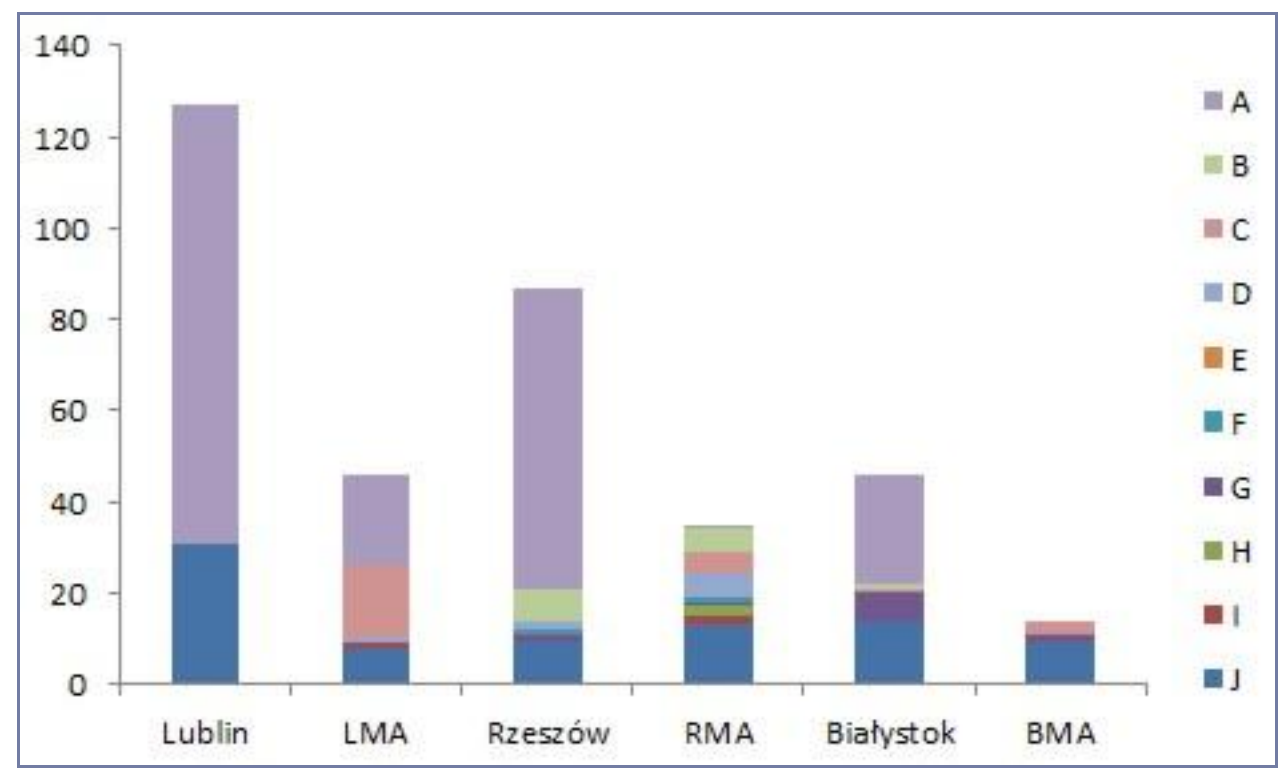

Fig. 10. Mass events in the Białystok, Lublin and Rzeszów Metropolitan Areas (2014)

A - Sports events; B - Interdisciplinary events; C - Other artistic-entertainment events; D - Combined events; E - Circus shows; F - Cabarets; G - Festivals; H - Film shows; I - Performances; J - Concerts

(author's own elaboration based on the Local Data Bank of the Central Statistical Office)

\section{Socio-cultural factors stimulating the development of metropolitan areas}

According to the study by HRYNIEWICZ (2000), socio-cultural factors have a considerably stronger effect on the development of regions than for example infrastructure. According to the author, social education and mobilisation stimulate the processes of development of entrepreneurship and economic infrastructure and contribute to attracting investment. All three metropolitan areas are important academic centres. The strongest traditions in this scope are those of Lublin. The first university in the city was established in 1918 and was the Catholic University of Lublin. In the postwar period, until the 1990s, it was the only stateindependent school of higher education in Poland. The higher school of Jewish studies, Jesziwa Chachmej, was established in Lublin in 1930. It functioned until the outbreak of the $2^{\text {nd }}$ World War. In October 1944, when the issues of the $2^{\text {nd }}$ World War were still unsolved, the Maria Curie Skłodowska University was established in Lublin. The city currently boasts four universities, i.e. schools of higher education of the highest importance. The number of students here is more than 70,000 (2013). More than 55,000 people study in Rzeszów, and approximately 35,000 in Białystok. The good position of Rzeszów in terms of higher education is evidence of the dynamic development of the city over recent years. The first school of higher education was established here in 1965 (Pedagogical University), followed by a branch of the Maria Curie Skłodowska University and a branch of the Cracow University of Life Sciences.

The analysis of data on the number of students suggests that in all three centres, as well as in entire region, the number has been decreasing since 2009. The most substantial decrease is recorded in the Białystok subregion, amounting to $25 \%$. The decrease in the Lublin subregion is $16 \%$, and in the Rzeszów area 13\% (Fig. 11). 


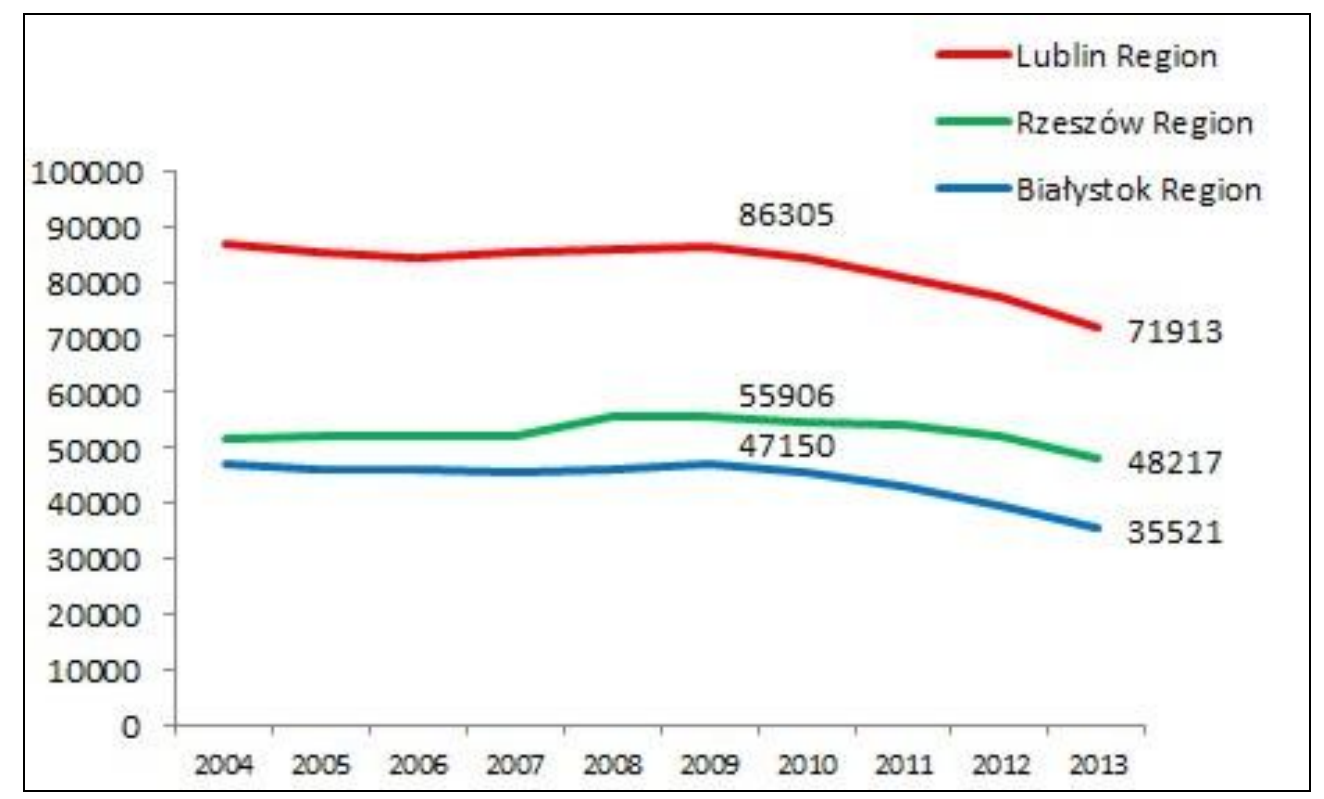

Fig. 11. Number of students in in Białystok, Lublin, and Rzeszów (2004-2013)

(Local Data Bank of the Central Statistical Office)

Lublin seems to be the strongest academic centre. The city also offers the highest number of study programmes and courses, and the offer of doctoral studies is the most developed. This suggests a high academic position of the schools of higher education in the city (Table 5). In the VI frame European programme, 44 research teams came from the schools of higher education in Lublin, only 21 from Rzeszów, and 13 from Białystok. Within this programme, only schools of higher education from Lublin cooperated with other academic centres (based on KRAJOWA STRATEGIA RozWOJU REGIONALNEGO, 2010). The schools of higher education in Rzeszów and Białystok undertook no such cooperation.

In spite of the leading role of Lublin in the field of higher education, The Rzeszów Metropolitan Area holds the dominant position in terms of educating its population. The percentage of population completed Bachelor or Master degree is the highest here, and the rate of population with elementary or incomplete elementary education - the lowest. In the Białystok Metropolitan Area, the latter group constitutes a total of almost $50 \%$ of the entire population. The same order is observed in the comparison of the central cities. The most favourable qualification structure occurs in Rzeszów, and the weakest in Białystok (Fig. 12). This reflects the cultural differences between the regions in the areas studied. Podkarpacie, as a region under industrial development since the late $19^{\text {th }}$ century, it has already developed a certain educational culture. The regions of Lublin and Podlasie are agricultural regions where education has always been of less importance.

The pattern of spatial variability of the population completed highest and lowest levels of education is interesting. Whereas in the former case evident similarity is observed between the areas, in the latter case considerable differences occur. In the Rzeszów Metropolitan Area, the share of people completed the elementary or incomplete elementary education level does not exceed $9 \%$ in any of the communes. The Lublin Metropolitan Area includes only several such communities. In the Białystok Metropolitan Area, such a situation is typical of more than half of the entire metropolitan area. The entire eastern zone covers areas where the share of people with the lowest education exceeds $9 \%$.

Table 5. Schools of higher education in Białystok, Lublin and Rzeszów (2014)

(Krajowa Strategia Rozwoju Regionalnego 2010, Ministerstwo Rozwoju Regionalnego)

\begin{tabular}{|l|c|r|r|r|r|c|}
\hline & $\begin{array}{c}\text { Total number of } \\
\text { higher education } \\
\text { institutions }\end{array}$ & Universities & $\begin{array}{c}\text { Technical } \\
\text { Universities }\end{array}$ & Other & $\begin{array}{c}\text { Number of } \\
\text { students }\end{array}$ & $\begin{array}{c}\text { Number of research } \\
\text { teams in the VI frame } \\
\text { European programme }\end{array}$ \\
\hline Białystok & 11 & 2 & 1 & 8 & 35521 & 13 \\
\hline Lublin & 9 & 4 & 1 & 4 & 71913 & 44 \\
\hline Rzeszów & 5 & 1 & 1 & 3 & 47995 & 21 \\
\hline
\end{tabular}




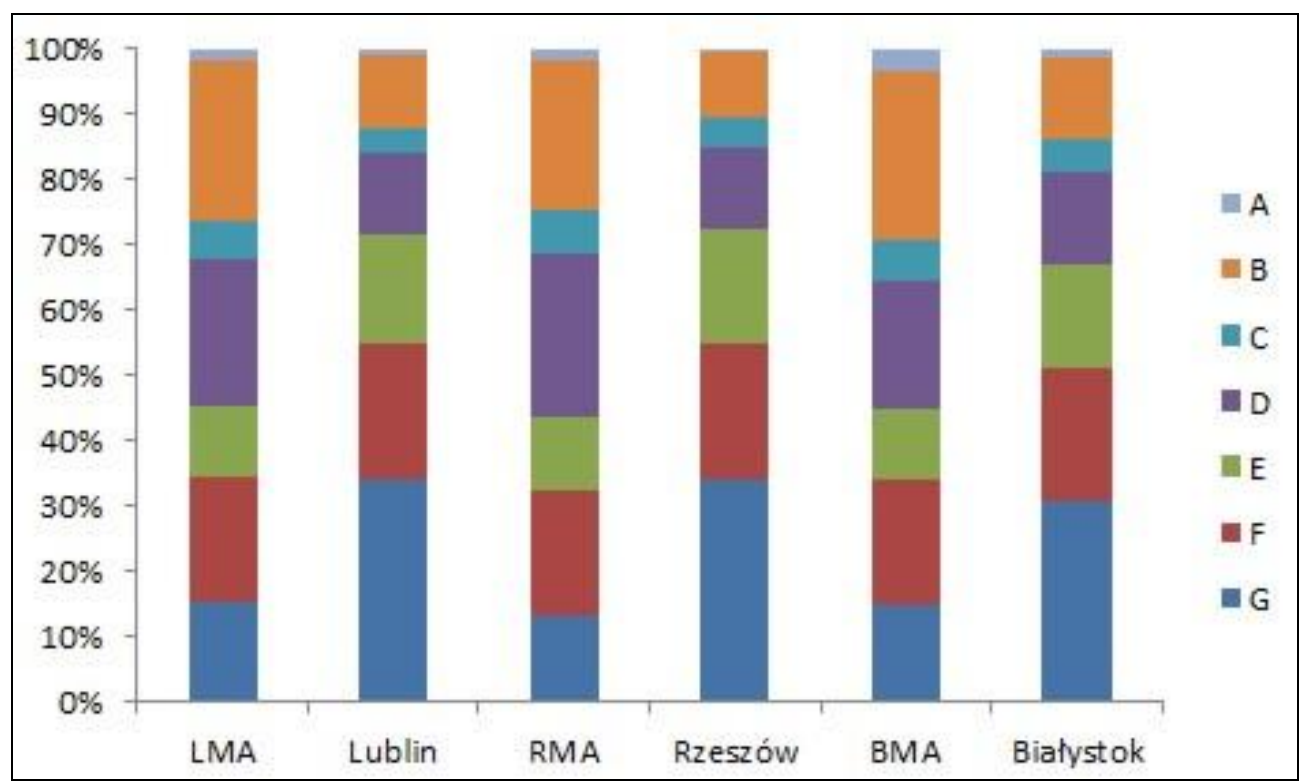

Fig. 12. Education of the population in the Białystok, Lublin, and Rzeszów Metropolitan Area (2011)

(author's own elaboration based on data from the Local Data Bank of the Central Statistical Office)

A - Incomplete elementary, no school education; B - Complete elementary education; C - Lower secondary education;

D - Basic vocational education; E - General secondary education; F - Secondary vocational education; G - Higher education

According to HRYNIEWICZ (2000), the strength of the region is also determined by social mobilisation, because social groups are a source of ideas, innovation and the facilitation of community life. Social mobilisation can be measured by the number of organisations in a given area. Białystok stands out among the cities in the study in this respect (Table 6). It features the highest number of clubs and diverse sports, as well as the number of their members and people using their facilities. Lublin is a leader in terms of performances of amateur bands, readings and lectures. Lublin dominates in terms of organised cultural events, shows by artists and professional bands and exhibitions. It is evident that in terms of social mobilisation the position of Rzeszów is considerably weaker than that of the other two cities.

Table 6. Sports clubs and cultural events in Białystok, Lublin and Rzeszów (2014)

(author's own elaboration based on data of the Local Data Bank of the Central Statistical Office)

\begin{tabular}{|c|c|c|c|c|}
\hline & & Białystok & Lublin & Rzeszów \\
\hline Sports clubs & Item & 106 & 79 & 76 \\
\hline Members & Person & 9182 & 7211 & 5986 \\
\hline Players & Person & 8439 & 6635 & 5793 \\
\hline Sports sections & Item & 206 & 148 & 160 \\
\hline Mass events & Item & 46 & 127 & 87 \\
\hline Exhibitions & Item & 43 & 69 & 34 \\
\hline Performances of amateur bands & - & 182 & 203 & 128 \\
\hline Performances of artists and professional bands & - & 111 & 211 & 14 \\
\hline Readings, meetings, lectures & Item & 284 & 368 & 63 \\
\hline Tourist and sports and recreation events & Item & 102 & 83 & 49 \\
\hline Competitions & - & 103 & 56 & 55 \\
\hline
\end{tabular}




\section{Conclusions}

It is undeniable that none of the cities in this study has currently developed sufficiently in accordance with those of the European metropolitan network. Each of the cities, however, strives to obtain the status of a metropolis and this is reflected, for example, in their formal status, economic and social activity.

The analysis of the statistical data presented shows no evident leader among the three metropolitan areas in all of the aspects discussed. Even the population criterion does not directly suggest which of the areas has the greatest chance of becoming a metropolis. The highest number of inhabitants and population density, and the best demographic situation occurs in the Rzeszów Metropolitan Area, but its central city has only approximately 200 thousand people, whereas Białystok has almost 300 thousand and Lublin 350 thousand. Lublin has a better historical position. It has existed as an urban settlement for more than 700 years, and almost from the beginning of its existence it was the most important centre of its region, concentrating administrative functions, of both state and the Church. It became the formal capital in 1474. Even the name of the region comes from the name of the city of Lublin. Therefore, Lublin has acquired cultural potential based on its historical position. It also has well developed academic functions. In the context of metropolitan aspirations, this may be of high importance. In economic terms, however, the Lublin Metropolitan Area is inferior to that of Rzeszów in many aspects.

It should also be emphasised that even if Lublin itself has a better position than Rzeszów, the Lublin Metropolitan Area treated as a whole is inferior to that of Rzeszów. The Rzeszów Metropolitan Area not only maintains better indices, but is also more compact, uniform, and more coherent with its metropolitan centre. This justifies its existence. The Lublin Metropolitan Area, and particularly the Białystok Metropolitan Area, are primarily made up of the central cities and these contain almost all of the entire business, social and cultural activities.
The data presented suggest that the existence and functioning of the Białystok Metropolitan Area is the least certain. Here the demographic processes are disturbing and do not offer a chance for population development in the area, or growth of its social potential. This is of particular concern for the communities near the borders with other regions. They are usually scarcely populated, and do not meet a number of economic criteria which would justify treating them as parts of a metropolis. The dynamic cultural development of Białystok seems does not seem to be enough of a factor for the development of the entire metropolitan area.

\section{References}

Castells M. 1998. The Information Age: Economy, Society and Culture - The rise of network society. 2, Oxford, Blackwell.

Gorzelak G., Smętkowski M. 2005. Metropolia i region. Wyd. Nauk. Scholar, Warszawa.

Hryniewicz J. 2000. Endo- i egzogenne czynniki rozwoju gospodarczego gmin i regionów. Studia Regionalne i Lokalne, 2(2): 53-77.

Ilnicki D. 2003. Miasta polskie jako potencjalne metropolie o znaczeniu kontynentalnym (próba identyfikacji). [in:] Jażdżewska I. (ed.) Funkcje metropolitalne $i$ ich rola $w$ organizacji przestrzeni. XVI Konwersatorium Wiedzy o Mieście, Łódź: 61-72.

Jałowiecki B. 2000. Społeczna przestrzeń metropolii. Wyd. Nauk. Scholar, Warszawa.

Koncepcja Przestrzennego Zagospodarowania Kraju 2030. www.mrr.gov.pl.

Kuć-Czajkowska K.A., Michałowski S. 2009. Metropolitalne szanse Lublina. Czas. Geogr., 80 (4): 189-209.

Markowski T., Marszał T. 2006. Metropolie, obszary metropolitalne, metropolizacja. Problemy i pojęcia podstawowe. KPZK PAN, Warszawa.

Nauka i technika w 2011 r. Informacje i opracowania statystyczne. Główny Urząd Statystyczny, Warszawa, 2012.

Parysek J.J. 2003. Metropolie: metropolitalne funkcje i struktury przestrzenne. [in:] Jażdżewska I. (ed.) Funkcje metropolitalne $i$ ich rola $w$ organizacji przestrzeni. XVI Konwersatorium Wiedzy o Mieście, Łódź: 19-40.

Smętkowski M., Jałowiecki B., Gorzelak G. 2009. Obszary metropolitalne w Polsce - diagnoza i rekomendacje. Studia Regionalne i Lokalne, 1(35): 52-73.

www.bialystok.gazeta.pl 